\title{
The Concept of Government Innovation Digital and Digital Government Measurement
}

\author{
Khadijah Nur ${ }^{1}$, Aulia Ramdhani Arief ${ }^{1}$ \\ hadijahnur1910@gmail.com \\ ${ }^{1}$ Governance Science, Faculty of Social and Political Science, University of Muhammadiyah \\ Makassar, Indonesia
}

Received: August 3, 2020

Received in Revised: August 11, 2020

Accepted: August 13, 2020

\begin{abstract}
Globalization is a phenomenon in which countries in the world directly or indirectly expect an interaction between people that is much more effective and efficient than previous times. Based on these circumstances, technology created to facilitate and improve the quality of human life shows its role. How is the effectiveness of implementing the SIAP (Education Application Information System) program online in improving the quality of services in the education sector in Banyuwangi Regency. The policy of implementing the B-DiSo (Banyuwangi Digital Society) program is impressed only as an ambition from the leadership, this can be seen from the obstacles in the development of digital friendly-based content, one of which is the application of online SIAP.
\end{abstract}

Keywords: Innovation Digital, Technology, Application

\section{Introduction}

Globalization is a phenomenon in which countries in the world directly or indirectly expect an interaction between people that is much more effective and efficient than previous times. The government is asked to be more responsive to the demands of its people (especially those who have to carry out their daily activities, such as doing business in an open market and free trade), to further improve their performance, bureaucracy and administration so that the quality of services to the community and those who have interests improves significantly.

Based on these circumstances, technology created to facilitate and improve the quality of human life shows its role. Because the majority of forms of government services to the community are matters relating to the collection, processing, and provision of various data, knowledge information, and policies and their dissemination to all members of society in need, it is clear that the most suitable technology to be applied here is technology, information, and communication. However, the fact that occurs in people's lives is a problem regarding the condition of society that has not maximized technology mindedness, most of them prefer to do something conventionally. So far, the use of information and communication technology by the community tends to be basic services, not productive use for activities that accelerate public services and general economic growth (Kaba \& Touré, 2014; Sugiyono, 2010).

Such conditions have made the Banyuwangi Regency Government produce a regional innovation program with the theme Banyuwangi Digital Society (B-DiSo) which was initiated from the smart city program with the hope of improving the quality of services and human resources in the fields of health, religion, education, taxation, tourism, and as in order to increase the 
economic growth of Banyuwangi Regency in general. The main task of the Education Office in the B-DiSo (Banyuwangi Digital Society) program is to provide services to the public in the field of education by utilizing information and communication technology. With the hope that if you apply information and communication technology, services, in general, can be more effective and of higher quality. Because with information and communication technology, barriers to distance, funding, and time can be minimized.

\section{Innovation Concept}

innovation is an instrument for developing new ways of using resources and meeting needs more effectively. Innovation can also be used to develop strategies and actions in public service explaining that there are three categorization levels of innovation, namely incremental innovation, radical innovation, and transformative innovation (Muluk 2008).

\section{Public Service}

According to Chapter, I Article 1 Paragraph (1) of Law Number 25 of 2009 concerning Public Services, what is meant by public service is an activity or a series of activities to fulfill service needs following laws and regulations for every citizen and resident of goods, administrative services andservices provided by public service providers. Efforts to improve service quality in the field of education are a planned strategic effort with certain aspects. Ten principles of public service are regulated in the Decree of the Minister for Empowerment of State Apparatus Number 63 / KEP / M.PAN / 7/2003 concerning General Guidelines for the Implementation of Public Services, these ten principles include simplicity, clarity, the certainty of time, accuracy, security, responsibility, completeness. work facilities and infrastructure, easy access, discipline, courtesy, hospitality, and comfort.

\section{Electronic Government}

Electronic administration develops by adopting electronic business, electronic commerce, electronic market. The first to apply this technology in business institutions is by using internet services. (Akadun 2009)

The implementation of electronic government can have a positive impact on governance among them, (a) improve the quality of government services to its stakeholders (society, business, and industry) especially in terms of performance effectiveness and efficiency in various in the field of state life, (b) increasing transparency, control and accountability of government administration in the context of implementing the concept of Good Corporate Governance, (c) significantly reduce the total administrative costs, relations, and interactions issued by the government and its stakeholders for daily activities (d) provide opportunities for the government to obtain new sources of income through its interactions with parties interested parties (e) create a new community environment that can quickly and accurately answer various problems faced in line with global changes and existing trends, and (f) empower the community and other parties as partners of the government in the process of taking various public policy equally and democratically (Indrajit 2002).

\section{Definition and Concept of B-DiSo}

B-DiSo is the result of a Memorandum of Understanding (MoU) between the Regent of Banyuwangi, Mr. Abdullah Azwar Anas, and PT Telekomunikasi Indonesia. This concept is called the Digital Society which seeks to create digital-friendly ecosystems. In terms of B-DiSo 
development, the Banyuwangi Regency Government seeks to build and develop content, including the construction of $10,000 \mathrm{WiFi}$ access points, launching e-office, e-health, eeducation, launching online ZIS (Zakat, Infaq, Alms) services.

\section{SIAP (Education Application Information System) Online}

SIAP (Education Application Information System) online is an information system service and online education application that connects parents, students, teachers, schools, regional and central agencies in an integrated and accountable manner for the advancement of Indonesian education. SIAP online can manage education data and information more quickly, easily, accurately, integrated, and continuously from the school level, city, district, provincial, to central education offices (Ministry of Education and Culture). Some of the advantages of the online SIAP (Education Application Information System), namely: (a) The system is completely online and real-time accessible at any time and from anywhere, (b) Affordable costs and minimal investment/capital, (c) The application is comfortable and complete according to the needs of every user (d) High scalability, safe, reliable, easy and fast to implement (e) Integrated with various other online facilities and services.

\section{Usefulness or Benefits of SIAP Online}

The principles of public services described above are sufficient to be used as guidelines for implementing SIAP online in Banyuwangi Regency. But the facts that occur show that the benefits of online SIAP have not been felt as a whole, it is only limited to filling in school profiles, teacher data, staff data, and student data. To update the daily test scores or report card scores have not been fulfilled and it can be concluded that the benefits of online SIAP have not been felt for the user. During one year running, this program still needs time to get to its maximum, in the sense that the applications contained in SIAP online can be used even more by schools, teachers, students, and parents and this takes quite a long time. (Budiani, 2007)

\section{Socialization in the Implementation of the SIAP Online Program}

The policy communication stage or what is often referred to as the socialization has been carried out by the Banyuwangi Education Office as the person in charge of the B-DiSo (Banyuwangi Digital Society) development program in the education sector. Socialization is a determinant of whether a local government program will be successful or not in the future. Socialization is the initial stage of policy implementation, namely how the Banyuwangi Education Office informs all schools that there is an online application program to manage school administration, not only informing but the education office must also explain in detail how and what is the content, purpose, the direction of the program so that the users, namely schools and the community (teachers, students, parents) can follow and properly prepare what to prepare and do to implement the new program.

\section{Achievement and Accuracy in the SIAP Online Program}

The fact that happened shows that the analysis and policy formulation process is not good enough, this is because the online SIAP program is run only following instructions from the Regent of Banyuwangi to develop an innovation program, namely B-DiSo (Banyuwangi Digital Society). The implementation of this program tended to have no clarity on where it started and what kind of policy formulation was because it seemed that it only supported the B-DiSo program, which is a regional government program. Also, Banyuwangi Regency also has different 
geographical conditions in each sub-district as well as different school conditions, so it appears that the implementation of this online program is not appropriate because it only creates a social gap between advanced schools and schools in remote areas. Constraints like that made this program less effective and it seemed that only the program that followed and supported the main program of the Banyuwangi Regent. (Widodo, 2013)

\section{Supporting factors for the SIAP Online program}

1) Facilities and Infrastructure

The facilities and infrastructure in the implementation of the online SIAP (Education Application Information System) program are PC / laptop and internet connection because this application is website-based. This will make it easier for users to use the SIAP online application because they don't have to bother to provide facilities and infrastructure. Users only need to open the website and $\log$ in using their respective accounts by entering their username and password.

2) Regulations that Support Implementation

SIAP Online The regulations that support the implementation of the online SIAP (Education Application Information System) in Banyuwangi Regency, these regulations have been stated in the Memorandum of Understanding which was signed and formalized by both parties, namely the Banyuwangi Regency Education Office and PT Telekomunikasi Indonesia. In the Memorandum of Understanding, it has been explained that the purpose of implementing SIAP online in the education office is to improve the quality of education services in general through the use of information and communication technology.

\section{Inhibiting Factors for the SIAP Online Program}

\section{1) Operational Technical Problems}

SIAP Online The operational technical problems in the online SIAP (Education Application Information System) program is related to the internet connection network. This is because the geographical conditions in Banyuwangi Regency are indeed different and when the installation will be carried out in remote areas, it will require a special internet network that will be assisted by service providers, namely PT Telekomunikasi Indonesia. So far, during the program, there appears to be a gap between remote schools and schools in the sub-district or district and this is since internet connections are not possible to be installed in remote areas.

2) User Mastery of Information and Communication Technology

The facts that occur show that the human resources in each school as user agencies are inadequate. This can be seen from the number of school operators in each school only amounting to one person and that one person will manage, handle, work on so many data collection applications that are instructions from the education office or directly from the center. So that the operators become overwhelmed in overcoming this problem. Moreover, at the lower level, namely SD, there are no school operators in the SD, so teachers who are experts and master the field of information and communication technology are also school operators. And this seems to be very detrimental to the teacher's time because the teacher's teaching focus time will be reduced and used to work on various kinds of data collection applications. 


\section{Conclusion}

The policy taken by the Regent of Banyuwangi, which is related to the use of information and communication technology in improving the quality of services in the education sector, is not the right policy. It can be seen that the application of online SIAP in Banyuwangi Regency has not yet reached the optimal point. Also, this online SIAP application policy seems to waste costs because the application used is only for online PPDB which only lasts 3 days of use. Academic data filling and financial reporting have not been carried out optimally. Based on this, it can be seen that the online SIAP application policy is only applied to support the program of the Banyuwangi Regent, namely B-DiSo (Banyuwangi Digital Society) so that the education office only follows instructions from the leadership. The policy of implementing the B-DiSo (Banyuwangi Digital Society) program is impressed only as an ambition from the leadership, this can be seen from the obstruction in the development of digital friendly-based content, one of which is the application of online SIAP. The policy implementers are less sensitive and do not know that the majority of people in Banyuwangi Regency have not been able to use a digitalbased service system so that only a small proportion of people who can master information and communication technology can benefit from this policy. This is why the development of information and communication technology in Banyuwangi Regency has not reached its effectiveness until now. So, it can be concluded that the implementation of the SIAP (Education Application Information System) program online for one year cannot be said to be effective.

\section{References}

Akadun (2009) Teknologi Informasi Administrasi. Bandung, Alfabeta.

Budiani, Ni Wayan. (2007) Efektivitas Program Penanggulangan Pengangguran Karang Taruna "Eka Taruna Bhakti" Desa Sumerta Kelod Kecamatan Denpasar Timur Kota Denpasar. [Internet], 2 (1). Diunduh dari: <http://www.pdfio.com/k-1921809.html> [Diakses pada 28 Februari 2014].

Indrajit, Richardus E. (2002) Electronic Government. Yogyakarta, Andi.

Kaba, B., \& Touré, B. (2014). Understanding information and communication technology behavioral intention to use: Applying the UTAUT model to social networking site adoption by young people in a least developed country. Journal of the Association for Information Science and Technology, 65(8), 1662-1674.

Muluk, Khairul M.R. (2008) Knowledge Management:Kunci Sukses Inovasi Pemerintahan Daerah. Malang, Bayumedia Publishing.

Sugiyono (2010) Metode Penelitian Kuantitatif, Kualitatif, dan R\&D. Cetakan ke-11. Bandung,Alfabeta.

Law Number 20 of 2003 concerning the National Education System. Jakarta, Kementerian Pendidikan dan Kebudayaan Republik Indonesia.Undang-undang Nomor 25 Tahun 2009 Tentang Pelayanan Publik. Jakarta, Pemerintah Republik Indonesia

Widodo, Joko M.S. (2013) Analisis Kebijakan Publik (Konsep dan Aplikasi Analisis Proses Kebijakan Publik). Malang, Bayumedia Publishing. 